\title{
백내장수술 후 발생한 Exophiala xenobiotica 진균안내염 Exogenous Fungal Endophthalmitis by Exophiala xenobiotica Infection after Cataract Surgery
}

\author{
김진영 · 박한상 · 강용구 \\ Jin Young Kim, MD, Han Sang Park, MD, PhD, Yong Koo Kang, MD \\ 경북대학교 의과대학 안과학교실 \\ Department of Ophthalmology, School of Medicine, Kyungpook National University, Daegu, Korea
}

\begin{abstract}
Purpose: To report a case of fungal endophthalmitis secondary to Exophiala xenobiotica after cataract surgery.
Case summary: A 79-year-old male presented with decreased visual acuity in the left eye 8 months after cataract surgery. He was diagnosed with uveitis and received subtenon triamcinolone injection, which has a temporary effect. Three months after the injection, his visual acuity had decreased, such that best-corrected visual acuity (BCVA) of the left eye was hand motion. Anterior chamber cells with hypopyon and severe vitritis with vitreous haze were observed in the left eye. We considered the possibility of endophthalmitis after cataract surgery, and repetitive anterior chamber irrigation with culture was conducted to identify pathogens. Systemic and intravitreal antifungal agents were injected after the isolation of Exophiala xenobiotica. However, there was no improvement of the endophthalmitis, and he underwent pars plana vitrectomy. Although inflammatory symptoms disappeared after surgery, black lesions in the corneal incision site were identified 3 months postoperatively. Ultimately, surgical debridement and anterior chamber injections of antifungal agents were performed for recurring endophthalmitis. After the surgery, there was no inflammation of the anterior chamber or vitreous cavity. The BCVA of the left eye improved to 0.5 .

Conclusions: Ophthalmologists should consider the possibility of fungal endophthalmitis in patients who suffer from uveitis-like symptoms after cataract surgery.
\end{abstract}

J Korean Ophthalmol Soc 2022;63(2):206-210

Keywords: Exophiala xenobiotica, Fungal endophthalmitis, Pars plana vitrectomy

안내염은 감염성 미생물의 전파를 통해 발생하는 안구 내 염증질환으로 원인 미생물에 따라서 세균성 및 진균성 안내염으로 구분하게 된다. 세균안내염과 마찬가지로 진균 안내염도 전파 경로에 따라 외상, 수술 중 오염된 기구, 결

- Received: 2021. 6. 10.

- Revised: 2021. 7. 15.

- Accepted: 2022. 1. 17.

- Address reprint requests to Yong Koo Kang, MD

Department of Ophthalmology, Kyungpook National University

Hospital, \#130 Dongdeok-ro, Jung-gu, Daegu 41944, Korea

Tel: 82-53-200-5814, Fax: 82-53-426-6552

E-mail: kykyuri@gmail.com

* Conflicts of Interest: The authors have no conflicts to disclose.
막 및 눈 주위의 여러 상재균에 의한 외인안내염과 혈행성 및 주변 조직의 염증에 의한 내인안내염으로 구분하게 된 다. ${ }^{1}$ 진균안내염은 세균안내염보다 드물게 발생하나, 증상 의 발현이 늦고 통증이 적은 반면 원인균의 배양이 어려운 특징을 갖는다. ${ }^{2}$

Exophiala 속에 의한 안내염은 매우 드문 질환이며, 그에 대한 증례 보고 역시 많지 않다. 따라서 저자들은 방수의 채취 및 배양을 통해 Exophiala xenobiotica 감염을 확인하 였고, 항진균제의 유리체강 내 주사 및 유리체절제술을 통 하여 치료한 증례를 경험하였기에 이를 보고하고자 한다. 


\section{증례보고}

기저질환이 없는 79 세 남자 환자가 2주 전부터 발생한 좌안 시력저하로 내원하였다. 환자는 8 개월 전 타병원에서 좌안 수정체유화술 및 인공수정체삽입술을 받은 이후 증상 없이 지내던 중 내원 2주 전부터 발생한 좌안 시력저하로 타병원에서 좌안 포도막염 의심하에 $1 \%$ prednisolone 점안 제(Predforte ${ }^{\circledR}$; Allergan, Irvine, CA, USA)를 하루 6회 점안 하였으나, 시력저하가 지속되어 본원으로 전원되었다. 내원 당시 우안 최대교정시력은 1.0 , 좌안 최대교정시력 0.6 으로 측 정되었다. 자동 비접촉안압계검사상 안압은 우안 $10 \mathrm{mmHg}$, 좌안 $10 \mathrm{mmHg}$ 였다. 세극등현미경검사상 좌안 결막의 충 혈 소견과 함께 전방염증, 안저검사상 유리체 염증이 관찰 되었다(Fig. 1A). 좌안 포도막염으로 진단하고 트리암시놀 론(Triam ${ }^{\circledR}$; Shinpoong Pharm. Co., Ltd., Ansan, Korea) 테 논낭하주사술을 시행하였으며, $1.5 \%$ lexofloxacin 점안제 (Cravit $^{\circledR}$ 1.5\%; Santen Pharmaceutical, Co., Ltd., Osaka, Japan) 하루 3회, $1 \%$ prednisolone 점안제(Predforte ${ }^{\circledR}$; Allergan)를 하루 4 회 점안하였다. 주사 1 개월 후, 환자 좌안 최대교정 시력은 0.8 로 호전되었고, 세극등현미경검사상 전방염증 및 안저검사상의 유리체염증은 사라졌고 점안제 사용을 중 단하였다.

주사 시행 3 개월 후, 환자는 좌안의 시력저하를 호소하였 고 좌안 최대교정시력 0.4 , 세극등현미경검사상 좌안의 전 방염증 및 섬모체염막, 안저검사상 유리체염증이 다시 확 인되어 포도막염의 재발로 진단하고 트리암시놀론 테논낭 하주사술을 시행하였다. 하지만 1 개월 후 시행한 검사상, 좌안 시력은 안전수동으로 확인되었고 세극등현미경검사 상 전방염증 및 전방축농이 확인되었으며 안저검사에서 유 리체염 및 유리체혼탁이 확인되었다(Fig. 1B-D). 트리암시 놀론 테논낭하주사술 이후 일시적으로 안구 내 염증은 호 전되었으나, 재발이 반복되어 포도막염보다는 백내장수술 이후 발생한 만성 안내염의 가능성을 고려하여 좌안 전방
세척술을 시행하면서 방수를 채취하여 그람 염색, 세균 및 진균 배양검사를 시행하였다. 배양검사 결과 $\mathrm{KOH}$ 도말검 사에서 양성이 확인되었고, 진균 배양의 중합효소 연쇄반 응검사에서 Exophiala xenobiotica가 확인되었다. 전신 항 진균제로 voriconazole 경구제(Vfend ${ }^{\mathbb{B}}$; Pfizer, Sandwich, $\mathrm{UK}$ )를 하루 $400 \mathrm{mg}$ 의 용량으로 복용하였고, 국소 항진균 제로 fortified voriconazole 점안제를 하루 4회 점안하면서 voriconazole $100 \mu \mathrm{g} / 0.1 \mathrm{~mL}$ 의 유리체내주사술을 1 주 간격 으로 5회 시행하였다. 유리체내주사술 후 전방축농은 일부 호전을 보였으나, 마지막 주사술 시행 2주 후 세극등현미경 검사상 좌안 전방염증 및 전방축농의 증가로 유리체절제술 을 진행하였다.

유리체절제술의 과정은 인공수정체 및 수정체낭의 제거 를 먼저 시행한 후, 후유리체박리 및 주변부 유리체의 제거 를 공막누르기를 통해 최대한 시행하였다(Fig. 2A). 항진균 제가 일으킬 수 있는 망막의 독성을 고려하여 유리체절제 술 과정 중 주변부 유리체의 제거 이후 액체-공기교환 전에 $500 \mathrm{~mL}$ 의 평형염액(BSS Plus ${ }^{\circledR}$; Alcon Laboratories, Fort Worth, TX, USA) voriconazole을 $10 \mathrm{mg} / \mathrm{mL}$ 의 농도로 혼 합하였다. 액체-공기교환 후 공기-실리콘기름 교환술을 통 해 5700 centistokes의 실리콘기름(Oxane ${ }^{\circledR}$; Bausch \& Lomb,
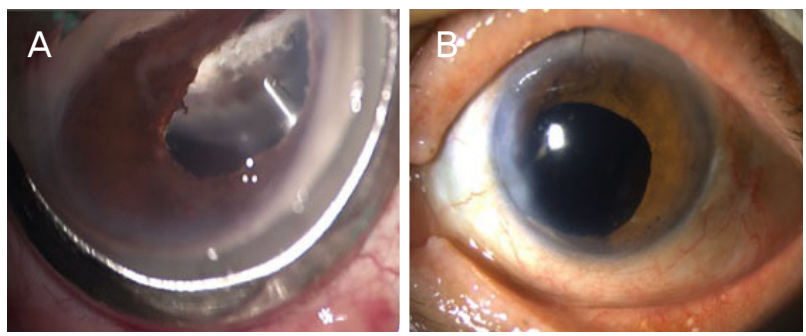

Figure 2. Clinical presentations during and after pars plana vitrectomy. (A) Fungal infiltrating lesions were seen in the pars plana during pars plana vitrectomy. (B) Anterior chamber cells and hypopyons were disappeared after pars plana vitrectomy.
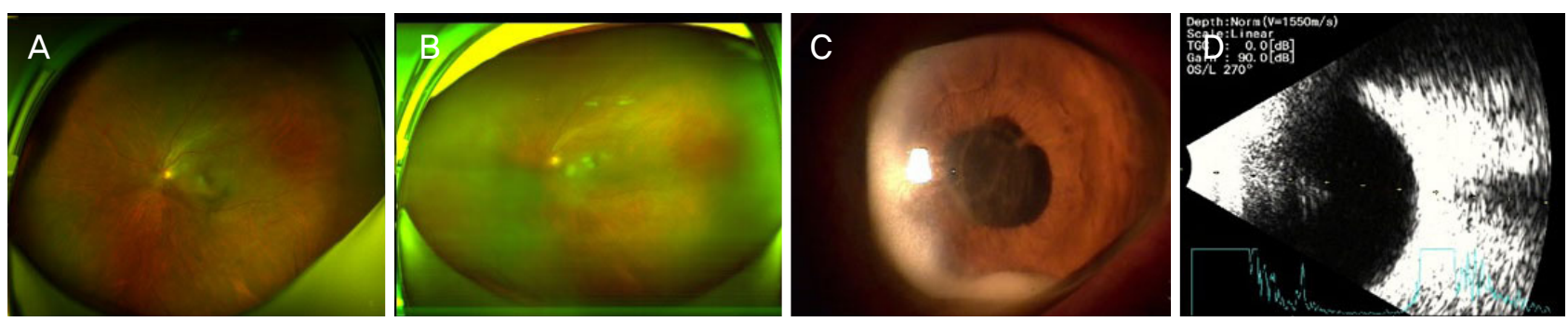

Figure 1. Anterior segment photograph, ultrasonograph, and fundus photographs of the left eye during the initial visit and after the subtenon triamcinolone injection. (A) Fundus photography shows mild vitritis at the initial visit. (B) Fundus photography shows severe vitritis with vitreous haziness 3 months after treatment. (C) Anterior chamber cells with hypopyons were shown in the left eye. 
Salt Lake City, UT, USA)을 상부공막절개를 통하여 수정 체 후면 또는 동공 위치까지 주입하였다(Fig. 2A). 유리체 절제술 시행 후 전신 항진균제로 voriconazole 경구제 (Vfend ${ }^{\circledR}$; Pfizer)를 하루 $400 \mathrm{mg}$ 2회 복용 및 fortified voriconazole 점안제를 하루 1 시간마다 점안하면서 추가적으 로 voriconazole $100 \mu \mathrm{g} / 0.1 \mathrm{~mL}$ 의 전방 주사술을 2일 간격 으로 총 4 회 시행하였다. 수술 2개월 후 전신 항진균제를 하루 $400 \mathrm{mg} 1$ 회 복용으로 감량하였으며, 수술 10주 후 부터는 전신 항진균제를 격일로 $400 \mathrm{mg} 1$ 회 복용으로 감 량 및 점안 항진균제 사용을 중단하였다. 전방축농 및 유리 체염의 호전으로 수술 3 개월 후부터 전신 항진균제 사용을 완전히 중단하였다(Fig. 2B). 수술 과정 중 인공수정체 및 수정체낭에 대한 배양검사를 다시 시행하였고 Exophiala xenobiotica가 동정되었다(Fig. 3).

하지만 전신 항진균제의 중단 1 주일 후부터 좌안의 시력 저하 및 전방염증이 발생하였으며, 중단 2주일 후 유리체절 제술 중 발생한 각막절개창의 각막내피에 검은색의 새로운 병변이 확인되었다(Fig. 4A). Exophiala xenobiotica에 의한 진균안내염의 재발로 진단하였고, 병변 부위의 수술적 조

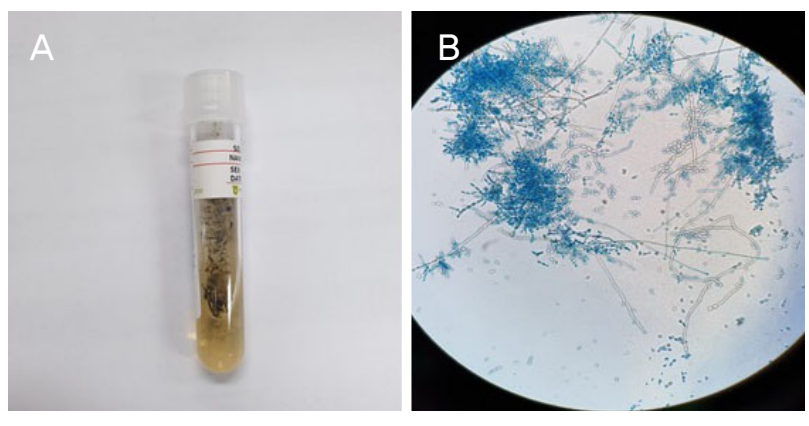

Figure 3. Fungal culture of Exophiala xenobiotica. (A) Gross photo of the melanin-producing black color fungal pathogen. (B) Microscopic view of Exophiala xenobiotica (Lactophenol cotton blue stain, $\times 400)$.
직제거술 및 voriconazole $50 \mu \mathrm{g} / 0.05 \mathrm{~mL}$ 의 전방주사술을 1 주 간격으로 3 회 시행하였다(Fig. 4B). 수술 과정 중 제거 된 조직에 대하여 진균 배양검사를 다시 시행하였고 균이 동정되지 않았다. 주사술 후 전방 및 유리체염증은 다시 발 생하지 않았고, 이후 재발없이 경과 관찰 중이다. 유리체절 제술 시행 1 년 후 마지막 방문에서 시행한 검사에서 좌안 최대교정시력 0.5 , 세극등현미경검사상 전방염증은 관찰되 지 않았고 안저검사상에서도 유리체염증은 확인되지 않았 다(Fig. 4C, D).

\section{고 찰}

진균안내염은 지역 및 기후에 따라 내인성 및 외인성 안 내염의 발생률이 다르다고 알려져 있다. ${ }^{3}$ Chakrabarti et $\mathrm{al}^{4}$ 의 연구에 따르면 진균안내염의 발생 기전은 내인성이 $11 \%$, 외인성이 $89 \%$ 의 빈도로 발생하였고, 원인이 되는 균 종은 Aspergillus 종이 가장 흔하였으며 Candida 종이 2번 째로 많았던 것으로 보고하였다. 이와 달리, $\mathrm{Kim}$ et $\mathrm{al}^{5}$ 은 국내에서 발생한 진균안내염 환자들을 대상으로 분석을 한 결과 $83 \%$ 의 환자가 내인성인 반면, $17 \%$ 만이 외인안내염이 었다고 보고하였다. 진균안내염의 원인균은 발생 기전과 관 계없이 Candida 종이 가장 흔하였고, 그 다음이 Fusarium 종이었다고 보고하였다. ${ }^{5}$ 따라서, 국내에서는 외인성 진균 안내염의 발생 빈도는 비교적 낮다고 판단할 수 있다.

Exophiala xenobiotica는 Exophiala 속 중 E. dermatitidis 다음으로 흔한 종으로 흙이나, 오염된 식물 근처에서 주로 생존하는 멜라닌을 생성하여 검은색을 나타내는 특징을 갖 는다. 주로 피부 감염을 통해 전파되며 폐렴, 뇌농양 등을 유발한다고 알려져 있다. ${ }^{6,7}$ Exophiala 속이 일으킬 수 있는 안구 감염은 각막염, 각막궤양, 괴사성 공막염, 안내염 등으 로 다양한 양상을 보이나 증례가 매우 드문 것으로 알려져 있다. ${ }^{6,8}$ Homa et $\mathrm{al}^{10}$ 은 1990 년 이후로 보고된 Exophiala
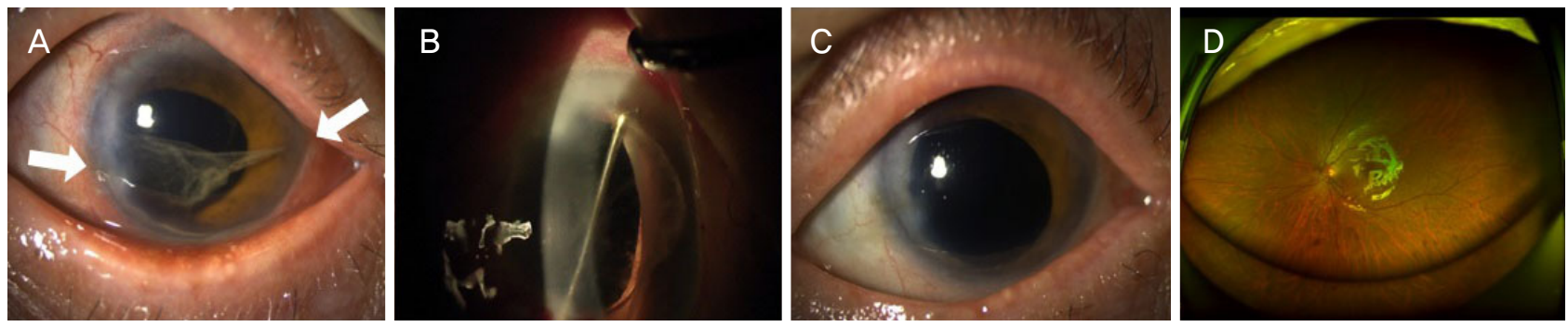

Figure 4. Anterior segment and fundus photographs of the recurrence and after the surgery. (A) There were anterior chamber cells and infiltrated lesions of the corneal incision sites (white arrows). (B) Surgical debridement with a 26-gauge needle tip and anterior chamber injection of the antifungal agent were conducted. (C, D) There was no more inflammation after the surgery in the anterior segment and fundus photography. 
속에 의한 안내염 증례들을 분석한 결과, E. jeanselmei, E. dermatitidis의 2종류의 균주가 배양되었다고 보고하였다. Exophiala 속에 의한 안내염은 일반적인 진균안내염과 같 이 초반에는 증상이 심하지 않으며, 이전에 보고된 증례들 에 따르면 최소 1 개월에서 최대 2.5 년까지, 평균 10 개월 정 도로 다른 균종에 의한 진균안내염보다도 더 느리게 진행 하고, 스테로이드에 일시적으로 반응하여 증상 및 염증 징 후가 호전되는 특징으로 인해 포도막염으로 오인되어 치료 가 지연된 경우가 많다고 알려져 있다. 본 증례에서도 진균 안내염의 임상양상이 백내장수술 이후 8 개월이 지난 이후 경미한 증상으로 시작되었고 포도막염과의 감별이 어려워 초기 스테로이드 치료를 하였으며, 스테로이드에 일시적인 치료 반응을 보임으로써 진균안내염의 진단 및 치료가 지 연되었다.

Exophiala 속에 의한 진균안내염 대한 명확한 치료의 가 이드라인은 아직 없다. 1990년대까지는 amphotericin B가 Exophiala 속의 눈 감염 치료로 우선적 치료로 사용되었으 나, 멜라닌을 생산하는 진균은 itraconazole 혹은 voriconazole과 같은 azole 계열에 감수성이 높은 것으로 알려 지면서 현재는 azole 계열들로 대체되어 사용되고 있다. ${ }^{6,11}$ 또한 Exophiala 속의 항진균제 최소억제농도에 대한 연구 결과에서는 voriconazole이 $0.03 \mu \mathrm{g} / \mathrm{mL}$ 로 가장 낮다고 보 고된 바 있다. ${ }^{12,13}$ 본 증례에서도 항진균제로 voriconazole 의 전신 및 유리체내주사술의 치료를 병행하였으나, 재발 의 양상을 유리체절제술을 시행하였음에도 국소적 재발로 추가적 치료가 필요하였다. 하지만 최종적으로 안내염의 임상양상 및 시력이 호전된 좋은 예후를 확인할 수 있었다.

본 증례는 백내장수술 이후 발생한 외인성 진균안내염이 만성적으로 발생한 증례로, 포도막염과 유사한 증상을 보 였으나 스테로이드 치료에 호전되지 않았다. 배양검사에서 Exophiala xenobiotica가 동정된 후 항진균제의 유리체내주 사와 전신 항진균제치료에도 불구하고 악화되어 유리체절 제술을 시행하였음에도 국소적인 안내염의 재발을 확인할 수 있었다. 결론적으로 백내장수술 이후 발생하는 포도막 염에 대해서 수술 후 만성적으로 발생할 수 있는 외인성 진 균안내염의 가능성을 염두에 두고 배양검사 및 적절한 항
진균제치료를 시행하는 것이 필요하며, 유리체절제술이 필 요할 경우 철저한 유리체 및 균주의 제거가 필요하다.

\section{REFERENCES}

1) Lemley CA, Han DP. Endophthalmitis: a review of current evaluation and management. Retina 2007;27:662-80.

2) Durand ML. Bacterial and fungal endophthalmitis. Clin Microbiol Rev 2017;30:597-613.

3) Barrios Andrés JL, López-Soria LM, Alastruey Izquierdo A, et al. Endophthalmitis caused by Fusarium: an emerging problem in patients with corneal trauma. A case series. Rev Iberoam Micol 2018; 35:92-6.

4) Chakrabarti A, Shivaprakash MR, Singh R, et al. Fungal endophthalmitis: fourteen years' experience from a center in India. Retina 2008;28:1400-7.

5) Kim DY, Moon HI, Joe SG, et al. Recent clinical manifestation and prognosis of fungal endophthalmitis: a 7-year experience at a tertiary referral center in Korea. J Korean Med Sci 2015;30:960-4.

6) Quintero-Estades JA, Walter S, Valenzuela F, Amescua G. Delayedonset postoperative endophthalmitis secondary to Exophiala. BMJ Case Rep 2015;2015:bcr2014208680.

7) De Hoog GS, Zeng JS, Harrak MJ, Sutton DA. Exophiala xenobiotica sp. nov., an opportunistic black yeast inhabiting environments rich in hydrocarbons. Antonie Van Leeuwenhoek 2006;90: 257-68.

8) Aggarwal S, Yamaguchi T, Dana R, Hamrah P. Exophiala phaeomuriformis fungal keratitis: case report and in vivo confocal microscopy findings. Eye Contact Lens 2017;43:e4-6.

9) Tsai TH, Chen WL, Peng Y, et al. Dematiaceous fungal keratitis presented as a foreign body-like isolated pigmented corneal plaque: a case report. Eye (Lond) 2006;20:740-1.

10) Homa M, Manikandan $P$, Saravanan V, et al. Exophiala dermatitidis endophthalmitis: case report and literature review. Mycopathologia 2018;183:603-9.

11) Chowdhary A, Meis JF, Guarro J, et al. ESCMID and ECMM joint clinical guidelines for the diagnosis and management of systemic phaeohyphomycosis: diseases caused by black fungi. Clin Microbiol Infect 2014;20 Suppl 3:47-75.

12) Silva WC, Goncalves SS, Santos DW, et al. Species diversity, antifungal susceptibility and phenotypic and genotypic characterisation of Exophiala spp. infecting patients in different medical centres in Brazil. Mycoses 2017;60:328-37.

13) Zeng JS, Sutton DA, Fothergill AW, et al. Spectrum of clinically relevant exophiala species in the United States. J Clin Microbiol 2007;45:3713-20. 


\section{= 국문초록 $=$}

\section{백내장수술 후 발생한 Exophiala xenobiotica 진균안내염}

목적: 백내장수술 후 발생한 Exophiala xenobiotica 감염에 의한 진균안내염 증례를 보고하고자 한다.

증례요약: 79세 남자 환자가 좌안 백내장수술 8개월 후 발생한 시력저하로 내원하였다. 내원 당시 좌안 포도막염으로 진단 후 트리암 시놀론 테논낭하주사술을 2회 시행한 후 증상의 호전을 보였다. 하지만 3개월 후 다시 좌안의 시력저하가 발생하였고, 전방축농 및 유리체혼탁이 확인되었다. 백내장수술 이후 발생한 만성 안내염의 가능성을 고려하여 좌안 전방세척술 및 방수의 배양검사를 통해 Exophiala xenobiotica 감염을 확인하였다. 항진균제의 전신 치료 및 유리체내주사술에도 불구하고 안내염은 호전이 없어 유리체절제 술을 시행하였다. 하지만 항진균제 치료의 중단 후, 각막절개창 부위의 안내염의 국소적 재발 소견으로 병변 부위의 수술적 조직제거 술 및 항진균제의 전방주사술을 시행한 후 전방 및 유리체염증 없이 좌안 최대교정시력은 0.5로 호전되었다.

결론: 백내장수술 이후 발생하는 포도막염에 대해서 수술 후 만성적으로 발생할 수 있는 진균안내염의 가능성을 염두에 두어야 한다. 〈대한안과학회지 2022;63(2):206-210〉

김진영 / Jin Young Kim

경북대학교 의과대학 안과학교실 Department of Ophthalmology, School of Medicine, Kyungpook National University

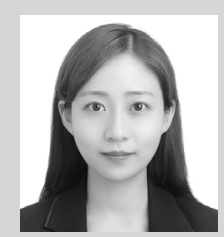

